\title{
ANALISIS PENGARUH PERBANDINGAN JUMLAH UDARA DAN AIR PADA HYDROPHORE AIR TAWAR TERHADAP POMPA PENGISIAN DI KAPAL WAN HAI 517
}

\author{
Muhammad Dedy Firdaus ${ }^{1)}$ Winarno ${ }^{2)}$ Rukmini ${ }^{3)}$ \\ Polieteknik IImu Pelayaran Makassar \\ Jalan Tentara Pelajar no. 173 Makassar, Kode Pos 90172 \\ Telp.(0411) 3616975; Fax(0411) 36288732 \\ E-mail : pipmks@pipmakassar.ac.id
}

\begin{abstract}
ABSTRAK
Tujuan penelitian ini adalah mengetahui perbandingan jumlah volume dan tekanan pada hydrophore agar tetap normal atau seimbang. Penelitian ini dilakukan pada MV. WAN HAI LINES Ltd. Sumber yang diperoleh dari tanggal yang tersedia dikapal dan dari buku panduan dan menggunakan metode analisa deskriptif. Hasil penelitian menunjukkan tekanan pada tanki yang tidak sesuai dengan ketentuan pada manual book menyebabkan proses supply mengalami kegagalan ataupun tidak maksimal. Perawatan yang dilakukan tidak sesuai maintenance plan menyebabkan kerusakan yang semula kecil menjadi lebih besar serta membutuhkan perawatan khusus ataupun perbaikan.
\end{abstract}

Kata kunci: hydrophore tank, fault tree analysis, pipa air tawar, suplai air tawar.

\section{PENDAHULUAN}

Untuk pengoperasian produksi air tawar terhadap hydrophore jika mengalami penurunan udara dan air harus dinormalkan kembali dengan mempertahankan jumlah udara dan air pada hydrophore air tawar terhadap pompa pengisian.

Untuk mempertahankan produksi jumlah udara dan air pada hydrophore air tawar sampai normal kembali, diperlukan Kegiatan perawatan berencana dan pemeliharaan terhadap tangki hydrophore harus dilakukan. Menjaga proses pemasukan dengan mempertahankan kevakuman ruang pada tangki, volume dan tekanan pada hydropore air tawar tetap seimbang.

Berdasarkan kejadian pada latar belakang di atas maka yang menjadi rumusan masalahnya adalah : bagaimana pengaruh antara 
jumlah udara dan air sesuai ketentuan pada hydrophore air tawar terhadap pompa pengisian.

Adapun tujuan yang ingin dicapai dalam penelitian ini adalah untuk mengetahui perbandingan jumlah volume dan tekanan pada hydrophore agar tetap normal atau seimbang.

Berdasarkan permasalahan yang dikemukakan diatas maka yang menjadi hipotesis dalam penulisan proposal penelitian ini di duga bahwa:

1. Jumlah tekanan udara yang rendah menyebabkan tidak terpenuhinya kebutuhan crew diatas kapal.

2. Proses perawatan terencana pada hydrophore kurang di persiapkan sehingga proses kerja pada hydrophore tidak berjalan sesuai rencana.

Menurut Asrori (2007) Pemeliharaan Terencana (Planned Maintenance)- Industrial kegiatan perawatan yang dilakukan dalam perawatan preventif adalah suatu bentuk pelaksanaan terjadwal oleh karena itu siklus perawatan menjadi penting keberadaannya.

Menurut Vanydn (2014) https://www.slideshare.net hydrophore (tangki tekan) pengertian dari pressure tank berfungsi untuk meringankan kerja pompa dari keadaan start-stop yang terlalu sering.

Menurut Daniela T (2016) tangki hidrofor atau hydrophore tank adalah water pressure tank atau yang sering juga disebut tangki air bertekanan. hydrphore tank adalah mangakumulasi tekanan pada pompa sampai mencapai tekanan tertentu atau tekanan yang diperlukan instalasi.

Menurut Wei Jie Wang (2018) dia mengatakan bahwan hydrophore merupakan tanki yang berfungsi menampung dan menyediakan air yang dimana menyuplai air dengan menggunakan udara tekanan dari tanki.

Menurut rumah pompa adalah tangki hydropore adalah tangki penyimpanan air sementara sebelum di alirkan ke seluruh bagian deck untuk keperluan air tawar sehari-hari. 
Menurut sales@indovessels.com tangki hydropore tank adalah water pressure tank di sebut juga tangki bertekan.Fungsi hydropore tank adalah mengakumulasi tekanan pada dari pompa sampai mencapai tekanan tertentu yang di perlukan instalasi. Misalanya untuk instalasi hot water system dimana water heater hanya dapat bekerja pada tekanan 3 atau 4 bar dengan adanya hydropore maka tekan tresebut dapat di pertahankan pada level $3 \mathrm{~kg} / 2 \mathrm{~cm}$ sampai dengan $4 \mathrm{~kg} / \mathrm{cm} 2$.

Menurut Jepry, A (2013) http://antonjepry.blogspot.com, prinsip kerja dari sistem tangki tekan (hidrophore) adalah sebagai berikut, air yang telah ditampung di dalam tangki bawah dipompa ke dalam tangki tertutup yang mengakibatkan udara didalamnya terkompresi sehingga tersedia air dengan tekanan awal yang cukup untuk didistribusikan ke peralatan plumbing di seluruh bangunan yang direncanakan.

\section{METODE PENELITIAN}

Jenis penelitian yang digunakan ialah kualitatif. Tempat penelitian yaitu pada kapal MV. Wan Hai 517.

Dalam melakukan penyusunan skripsi ini, penulis menggunakan cara atau metode yang ada yaitu Metode lapangan (field research) dan Metode kepustakaan (library research).

Objek yang akan diteliti pada penelitian ini adalah faktor-faktor apa saja yang menyebabkan terjadinya perbandingan jumlah udara dan air pada hydrophore di kapal. Dengan sumber data diperoleh dari data primer dan data sekunder.

\section{HASIL PENELITIAN DAN PEMBAHASAN}

A. Analisa

Penggunaan hydrophore tank diatas kapal sangatlah penting untuk menunjang kehidupan crew di atas kapal maupun untuk mesin pada MV. Wan Hai 517 sehingga memerlukan perawatan dan pemahaman cara pengoperasian dari hydrophore tank. Agar 
penggunanaan hydrophore ini dapat bekerja dengan baik.

Berdasarkan pengamatan, terdapat kurang optimalnya suplai air tawar diakibatkan karena jumlah udara dan air pada hydrophore air tawar mengalami kebocoran pada pipa dan safety valve.

Tabel 1. Pengukuran Tekanan Hydrphore

\begin{tabular}{|l|l|l|l|l|}
\hline \multirow{2}{*}{ NO } & \multirow{2}{*}{$\begin{array}{l}\text { Waktu } \\
\text { jam) }\end{array}$} & \multirow{2}{*}{$\begin{array}{l}\text { R/H } \\
\text { Pump }\end{array}$} & \multicolumn{2}{|l|}{ Tekanan $(\mathrm{Kg} / \mathrm{cm} 2)$} \\
\cline { 5 - 5 } & & & Low Press. & High Press. \\
\hline 1 & $04-08$ & Auto & 4 bar & 5 bar \\
\hline 2 & $08-12$ & Auto & 4 bar & 5 bar \\
\hline 3 & $12-16$ & Auto & 4 bar & 5 bar \\
\hline 4 & $16-20$ & Auto & 4 bar & 5 bar \\
\hline 5 & $20-00$ & Auto & 3 bar & 4 bar \\
\hline 6 & $00-04$ & Auto & 3,7 bar & 4 bar \\
\hline NO & Waktu & R/H & Tekanan $(\mathrm{Kg} / \mathrm{cm} 2)$ \\
& & Pump & Low Press. & High Press. \\
\hline 1 & $04-08$ & Auto & 2 bar & 5 bar \\
\hline 2 & $08-12$ & Auto & 2 bar & 5 bar \\
\hline 3 & $12-16$ & Auto & 2 bar & 5 bar \\
\hline 4 & $16-20$ & Auto & 2.5 bar & 5 bar \\
\hline 5 & $20-00$ & Auto & 3 bar & 4 bar \\
\hline 6 & $00-04$ & Auto & 2,7 bar & 4 bar \\
\hline
\end{tabular}


1. Terjadinya kebocoran pada pipa

a. Penanganan terjadinya kebocoran pada pipa supply udara hydropore pemeriksaan serta perbaikan harus dilakukan dengan ketelitian dan menjaga bagian-bagian yang telahbocor.

Adapun hal-hal yang diperhatikan dalam melaksanakan perbaikan pada pipa hydropore yaitu :

1) Pertamakali yang harus kita perhatikan dalam melaksanakan perbaikan pada pipa hydropore udara yaitu mempersiapkan sparepart yang akan di ganti setelah semua sparepart sudah siap maka kita membuka bagian yang akan di ganti setelah di buka bersihkan semua bagian sehingga sparepart yang baru dapat berfungsi sebagaimana mestinya

2) Lakukanpengecekanpada pipa yang telah di ganti dan setelah di lakukan pengecekan pada pipa yang telah di ganti maka harus di lakukan pengetesan pada hydropore untuk mengetahui apakah pipa yang telah di ganti berfungsi sebagaimana mestinya.

3) Pada saat melakukan perbaikan pada hydropore harus selalu memperhatikan segala aspek yang berpedoman pada manual book dan di sesuaikan dengan standar

4) Lakukanpembersihansetiap saat agar tangki hydropore selalu dalam keadaan bersih selain itu kita juga lebih mudah melihat kebocoran jika ada di setiap pipa

5) Saat melakukan tes pada hydoropore maka kita perlu memperhatikan semua sambungan pipa 

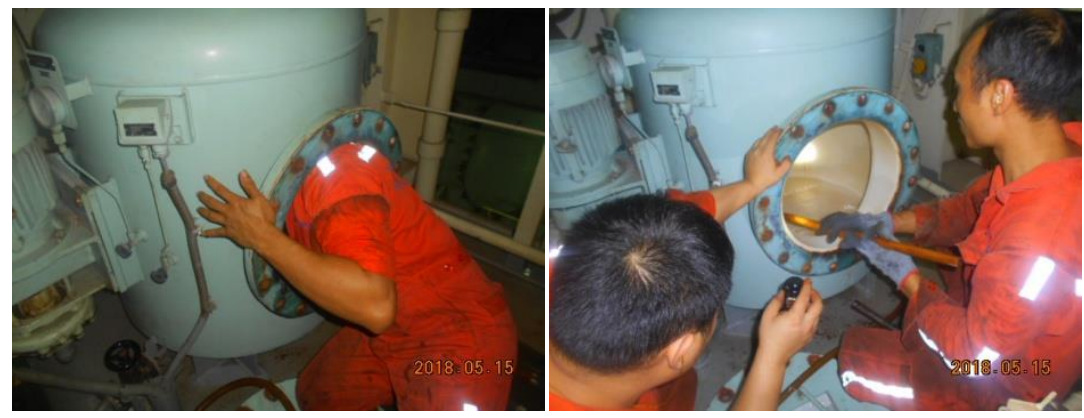

2. Perawatan yang kurang optimal pada tangki hydropore

a. Kurang optimalnya perwatan di karnakan kurangnya pasokan sparepart yang di supply sehingga crew kapal tidak bisa berbuat apa-apa selain.

1) Menggunakan sparepart yang ada meskipun tidak maksimal bekerja pada hydropore.

2) Lakukan perbaikan seadanya pada tangki hydropore

3) Pengencakan dilakukan dengan terus menerus karena sparepart pada hydoropore yang telah di pasang dalam keadaan rusak.

3. Penanganan terhadap kurang perawatan pada tangki hdyropore untuk mengatasi kurangnya perwatan pada tangki hydropore maka yang dilakukan adalah :

1). memperlancar pasokan sparepart ke kapal agar para cruw kapal mudah merawat

2). Bongakar dan ganti komponen yang rusak dengan yang baru

3). Perhatikan sparepart yang di ganti apakah sudah sesui dengan yang di ganti typenya

4). Perhatikan setiap sambungan pipa agar tidak ada udara yang keluar

5). Periksaotomatis detektor apakah sudah bekerja dengan baik sesuai tekanan yang dibutuhkan 
6).Keberdayaan manusia di dalam perawatan hydropore setidkanya orang yang merawat hydropore tersebut mengetahui atau menguasai seluk beluk tentang cara kerja dan kegunaan tangki hydorpore.Jika hal ini di lakukan oleh SDM yang tidak menguasai tentang hydropore maka itu dapat membuat kerusakan yang bartambah bukan membuat tangki hydropore berfungsi sebgamana mestinya di sebakan mungkin karna pemasangan yang tidak tepat

Setelah mengetahui faktor yang dapat menyebabkan tidak lancarnya pengoperasian hydrophore tank maka dapat kita ketahui dengan cara penanganan terhadap masalah yang terjadi. Seperti mengetahui betul cara pengoperasian hydrophore tank dan kebocoran yang terjadi. Mengatasi masalah tersebut yaitu dengan cara ketika pompa hydrophore kita matikan maka otomatis tekanan pada air akan menurun dan tekanan pada udara akan lebih banyak, maka masinis 4 mengurangi tekanan udara pada hydrophore tank sampai level pada air hampir penuh. Setelah tekanan udara kita lepaskan sehingga normal barulah kita dapat membuka valve untuk air tawar sehingga jumlah tekanan pada pompa dapat normal kembali menjadi kurang lebih $6 \mathrm{~kg}$.

\section{KESIMPULAN DAN SARAN}

A. Kesimpulan

1. Tekanan pada tanki yang tidak sesuai dengan ketentuan pada manual book menyebabkan proses supply mengalami kegagalan ataupun tidak maksimal.

2. Perawatan yang dilakukan tidak sesuai maintenance plan menyebabkan kerusakan yang semula kecil menjadi lebih besar serta membutuhkan perawatan khusus ataupun perbaika. 
B. Saran

1. Safety valve dan semua komponen pendukung agar dapat diperhatikan setiap maintenance atau perawatan terhadap mesin dan sparepart tersebut tersedia.

2. Perawatan atau maintenance harus dilakukan secara teratur agar pengoperasian dan penggunaan hydrophore dapat bekerja dengan baik.

\section{DAFTAR PUSTAKA}

[1]. Asrori (2007) Pemeliharaan Terencana (Planned Maintenance) Industrial. Diakses pada tanggal 5 juni 2018

[2]. Daniela T,(2016). Pengertian hydrophore. (https://www.sandfiltercarbonfilter.com). Diakses pada tanggal 5 juni 2018.

[3]. Jepry, A,(2013). Prinsip kerja hydrophore. (http://antonjeprysugiarto.blogspot.com). Diakses pada tanggal 5 juni 2018.

[4]. Rahyono ,(2018). Sistem Perawatan Hydrophore. (http://repository.pipsemarang.ac.id/952/14/PROSIDING.PDF). Diakses pada tanggal 5 juni 2018.

[5]. Vanydn,(2014). Pengertian hydrophore dan fungsi pada hydrophore (https://www.slideshare.net). Diakses pada tanggal 5 juni 2018.

[6]. Wei Jie Wang (2018). Pengertian Hydrophore. Pada tanggal 20 november 2018 